\title{
Asteroseris from the Bersek Marl (Gerecse Mountains, Hungary; Early Cretaceous; Anthozoa)
}

\author{
Hannes LösER ${ }^{1}$ \& István FöZY ${ }^{2}$ \\ ${ }^{1}$ Universidad Nacional Autónoma de México, Instituto de Geología, Estación Regional del Noroeste, \\ Apartado Postal 1039,83000 Hermosillo,Sonora, Mexico.E-mail: loeser@paleotax.de \\ ${ }^{2}$ Department of Palaeontology and Geology, Hungarian Natural History Museum, \\ H-1083 Budapest, Ludovika tér 2, Hungary.E-mail: fozy@nhmus.hu
}

\begin{abstract}
The small cupolate solitary coral Asteroseris is reported from Late Valanginian to Hauterivian marls from the Bersek Hill (Gerecse Mountains, Northern Hungary). The material is poorly preserved and the taxonomic assignation is difficult. The present findings indicate the earliest occurrence of the genus and family. With 3 figures.
\end{abstract}

Key words - Asteroseris, azooxanthellate coral, Early Cretaceous, Hungary

\section{INTRODUCTION}

In the years of 1963 and 1964 an intensive fossil collecting campaign was carried out by the team of the Hungarian Geological Institute from the uppermost part of the cement quarry of Bersek Hill (Gerecse Mountains, Northern Hungary). The collecting was realised by Tibor Steiner and co-workers, and the project was supervised by the late Prof. József Fülöp. The study of the collection started after the death of Prof. Fülöp in 1998.

The first preliminary stratigraphic and taxonomic conclusions were based upon ammonite and nannoplankton studies (FőZY \& FoGARASI 2002). Biostratigraphical results, mainly based on ammonites, were later updated by Fözy \& JANSSEN (2009).

Corals are only subordinated faunal elements. Zooxanthellate corals (z-corals, hermatypic corals) lived and live only in shallow marine environments because the symbiontic dinoflagellates they live with require light. Azooxanthellate corals (az-corals, ahermatypic corals), those found in the Bersek Hill section, lived and live also in deeper environments because they do not require light. Extant az-corals have a high generic diversity (e.g. CAIRns \& Kitahara 2012). This was not always the case; az-corals were not diverse during the Jurassic and 
Early Cretaceous; they gained diversity only with increasing temperature of marine surface waters and more frequent oceanic anoxic events from the Aptian on (LÖSER et al. 2013, textfig. 1). The study of az-corals is more complicated than that of z-corals. Az-corals are mainly solitary and small. They do not allow multiple thin sections like colonial z-corals. For this reason az-corals are less well studied and less well known. With the present short paper we try to contribute to the literature about Early Cretaceous az-corals.

Early Cretaceous corals from Hungary were reported mainly by KoLOSVÁRY (1954, 1957, 1959) and CSÁszÁR \& TURNŠEK (1996). Whereas the latter reference provides exact descriptions and illustrations of the material, the compilations by Kolosváry are less precise and give only a rough idea about Hungarian Cretaceous corals.

\section{GEOLOGICAL SETTING}

The fossils were collected in the Bersek Quarry on the Bersek Hill in the Gerecse Mts, close to the Danube River, south of the village Lábatlan. Geographical coordinates are $47^{\circ} 43^{\prime} 13^{\prime \prime} \mathrm{N}, 18^{\circ} 31^{\prime} 42^{\prime \prime} \mathrm{E}$. The region belongs to the Transdanubian Range, representing the north-eastern segment of the Bakony Unit (KÁZMÉr 1986) forming the Austroalpine part of the AlCaPa terrane (Csontos \& Vörös 2004). The topographic and structural position of the studied locality is shown in Figure 1. The Early Cretaceous age of the siliciclastic rocks of the Gerecse Mts was already recognised by the pioneers of Hungarian geology (HANT KEN 1868, HOFMANN 1884). FÜLÖP (1958) subdivided the succession at the stage level.

The major part of the Bersek Quarry comprises monotonous, grey marlstone (Bersek Marl Formation; CsÁszÁR 1996). The thick lower part, Valanginian in age, is very poor in megafossils, whereas the upper, approximately 15 metres of the marl, is relatively rich in cephalopods.

\section{MATERIAL AND METHODS}

Fossil samples were derived from five subsections within the quarry and were collected bed-by-bed. The order of sections from the oldest to the youngest is C, B, A, D (Fig. 2). Coral samples were found only in the Bersek Marl, in Section $\mathrm{C}$, which means that they are Late Valanginian and Hauterivian in age. The other sections did not yield any coral. 


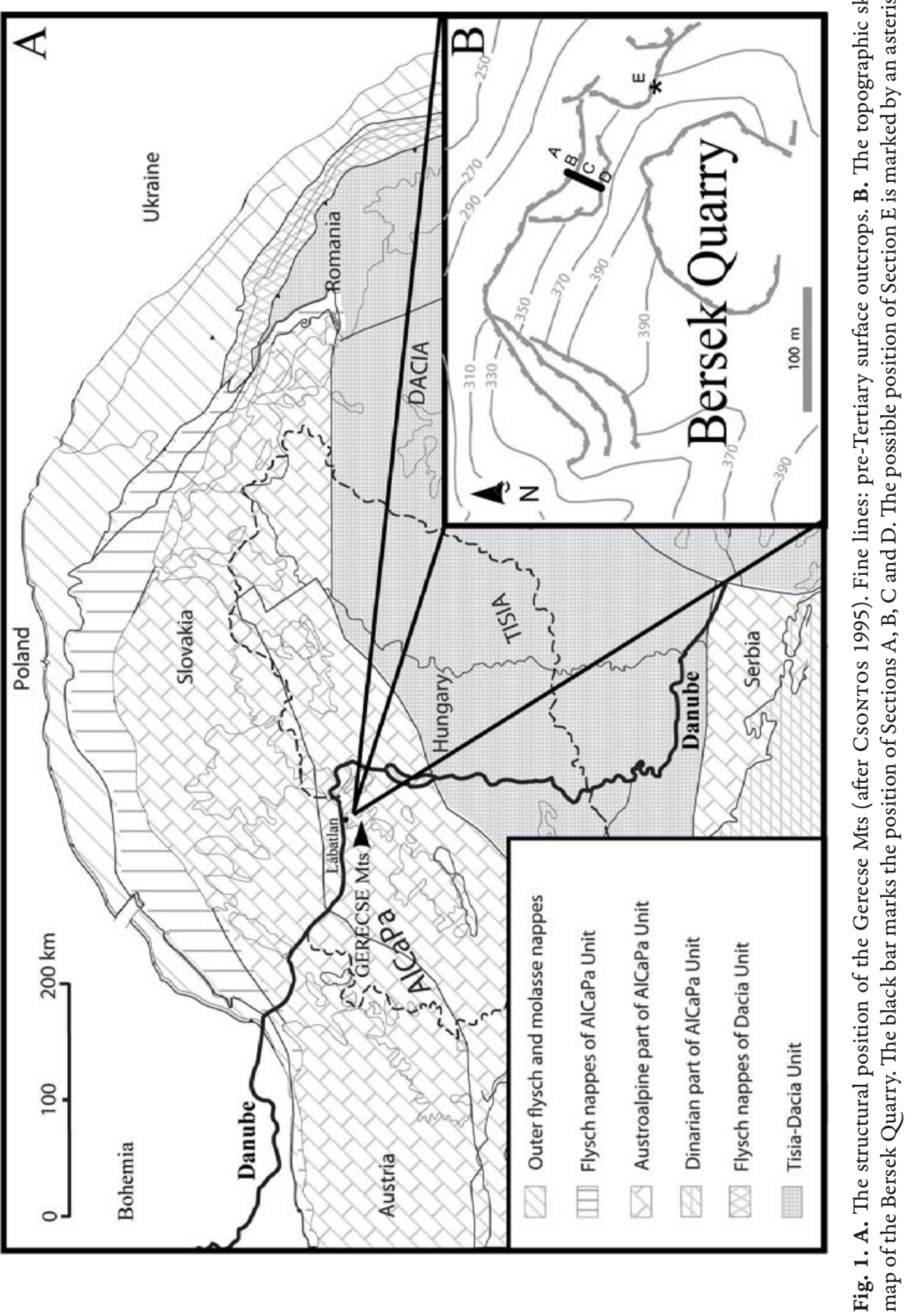




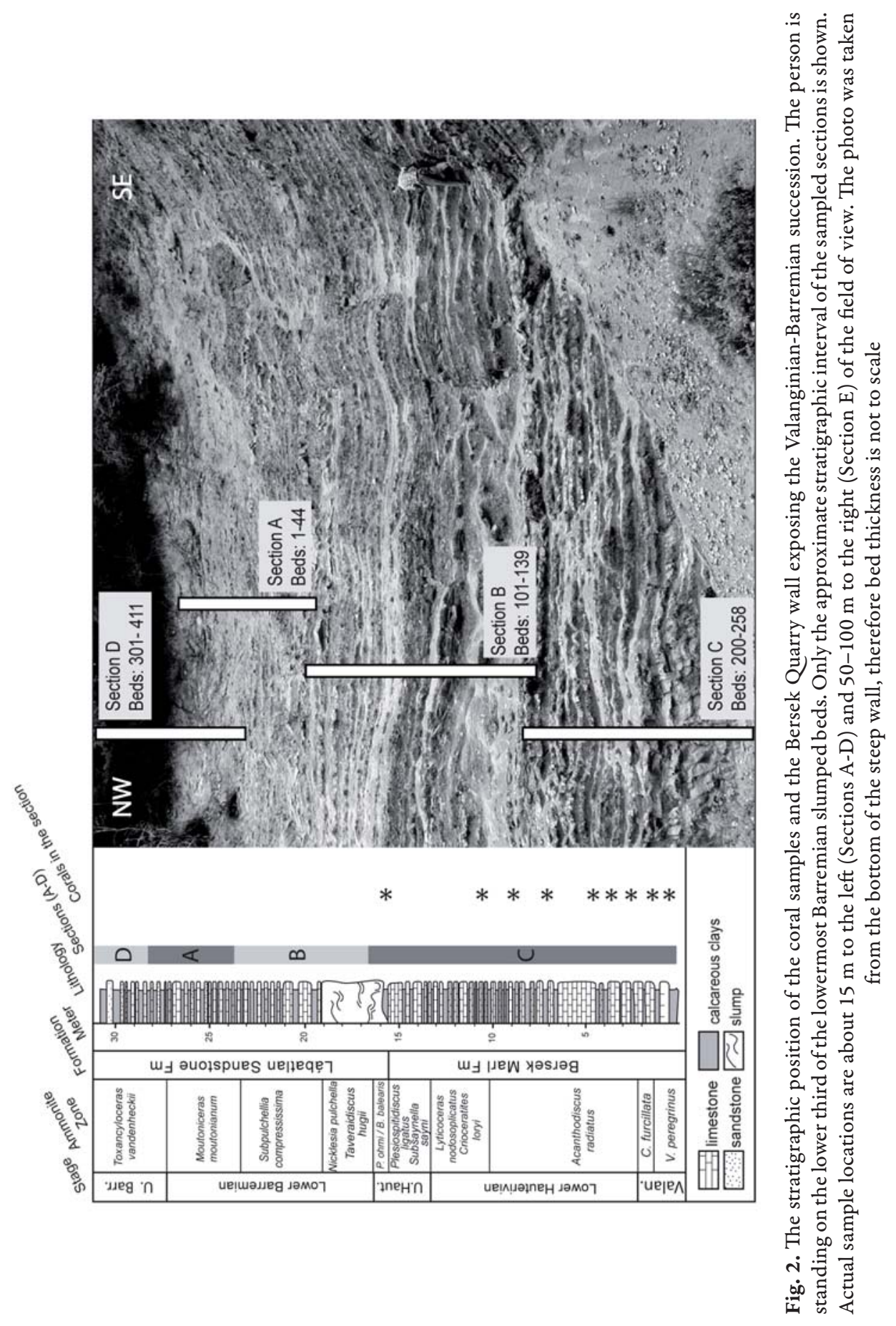




\section{SYSTEMATIC DESCRIPTION}

\section{Phylum Cnidaria Milne-Edwards, 1857 \\ Class Anthozoa Ehrenberg, 1831 \\ Order Scleractinia Bourne, 1900}

Corals are represented by two types, a small solitary cupolate coral species which occurs throughout the whole section $C$, and various small turbinate solitary corals which are restricted to bed 221 . The material is poorly preserved. Most of the cupolate corals are preserved only as external moulds; in rare cases they present remains of the septa. The septa are not preserved in the turbinate corals, only the thin wall, which is probably a secondary filling of the mould. Therefore, a determination can be given only for the cupolate form.

\section{Suborder Fungiina Verrill, 1868-70 \\ Family Asteroseriidae, 1952 \\ Genus Asteroseris Fromentel, 1867}

Type species - Stephanoseris coronula Fromentel, 1863 by monotypy.

Asteroseris is a small solitary patellate coral with a circular outline. The septa are compact. The microstructure of the septa is unknown. They are in cross section externally slightly thicker, and slightly thinner towards the centre, with a maximum thickness of $250 \mu \mathrm{m}$. The symmetry of the septa is radial and regularly hexameral, with regular cycles. The cycles differ in length, but almost not in thickness. The septa of the first cycle extend to the centre of the calice; later cycles are shorter. The septa of younger cycles are often and regularly connected to the septa of preceding cycles. The septal upper margin is unknown. The lateral septal face occasionally shows small thorns; the inner margin is unknown. Pali or paliform lobes are absent. All septa of the first cycle are attached to the columella. The costae are unknown. Synapticulae are present. The columella is formed by septal fusion in the centre of the calice. Endotheca and the wall are unknown.

Asteroseris was originally indicated in the Cenomanian of Le Mans (France), later in the Early Albian of France and Iran, and the Early Aptian of Greece. Apart from the type species, two questionable Late Cretaceous species are known that probably do not belong to this genus (see LösER 2013 for more details).

\section{Asteroseris sp.}

(Fig. 3)

Description - Small solitary cupolate coral with a diameter of $10-15 \mathrm{~mm}$ (rarely up to $18 \mathrm{~mm}$ ) and a height of about 3-6 mm. The septa are thick, com- 
pact and in a regular hexameral symmetry. Twenty-four septa reach the centre of the calice. The remaining 24 septa are shorter and connected to 12 large septa. Synapticulae are common, but not so regular as in the type species. The endotheca is absent. The wall and centre of the calice are unknown. The outer surface of the wall (= bottom of the coral) is wrinkled and shows concentric growth lines.

Remarks - The material differs from the type species by a higher calicular diameter. There are no other species: $A$. vidali Reig Oriol, 1989 and $A$. formosus Reig Oriol, 1995 are too poorly preserved to assign them to any genus; Funginella isfahanensis Yazdi et al. 2011 is a junior synonym of the type species.

Occurrence - The coral was found throughout the whole section C (bed numbers $204,211,225,226,228,233-36,239-43,251-52,255)$ encompassing the interval from the Late Valanginian (Peregrinus Zone) to the top of the Hauterivian.

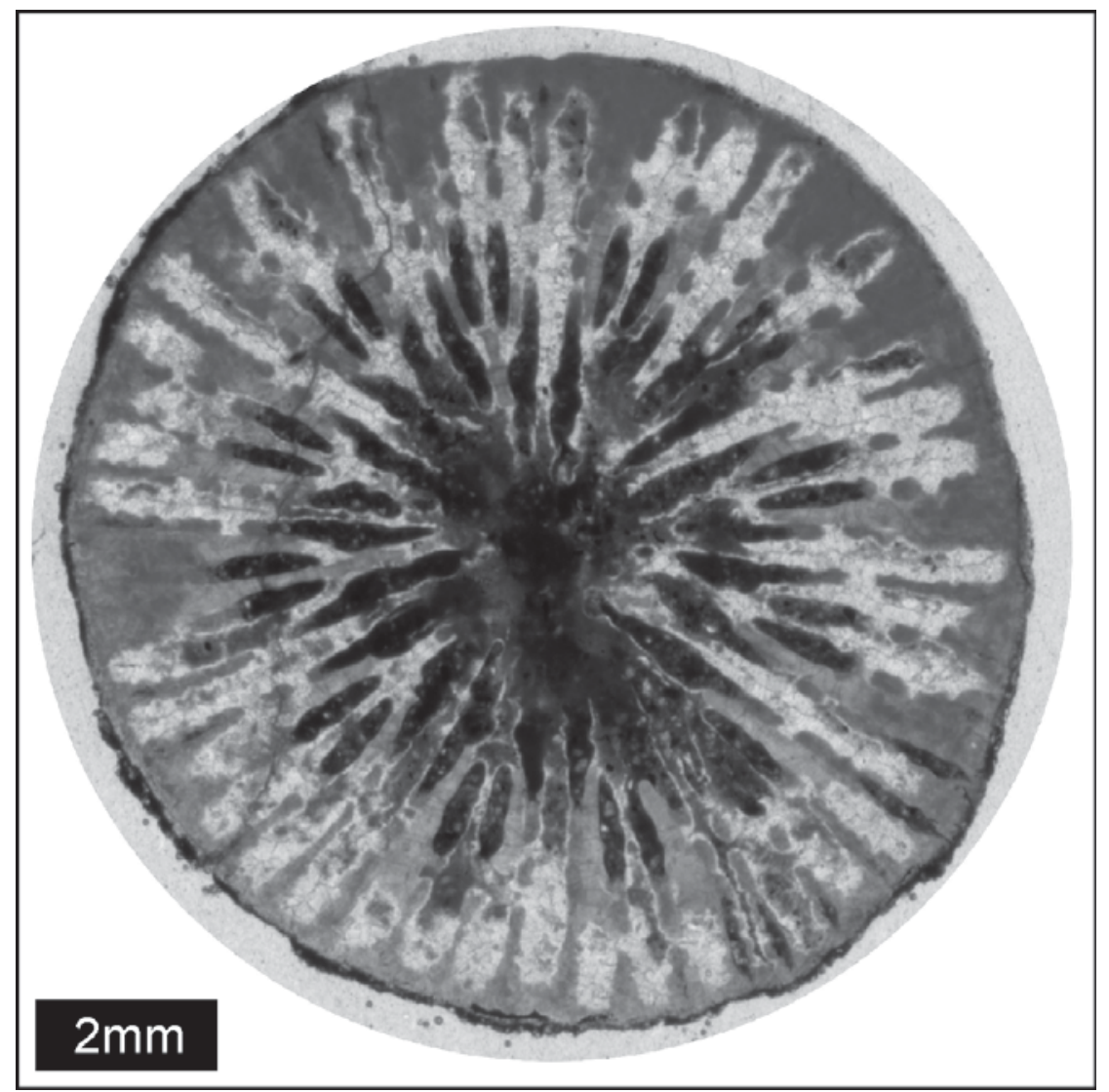

Fig. 3. Asteroseris sp. Transversal thin section. Specimen INV 2015.3. (Hungarian Natural History Museum, Budapest) 


\section{DISCUSSION}

By its shape, Asteroseris is well adapted to soft bottom environments. Very probably it was an azooxanthellate coral that did not live in symbiosis with algae and therefore could live in deeper marine environments. The present findings indicate the earliest occurrence of the genus and family. Other genera of the family are known from the Hauterivian on. Because of the rarity of these corals and the difficulty of observation (preparing thin sections causes complete loss of the specimen), taxonomy and evolution of these early Fungiids are still poorly known.

Acknowledgements - A grammatical check was carried out by Proof-Reading-Service (Letchworth Garden City, England). Preparation of thin sections in the ERNO laboratory by Aimée Orcí (Hermosillo, Sonora, Mexico) is gratefully acknowledged.

\section{REFERENCES}

CAirns S. D. \& Kitahara M. V. 2012: An illustrated key to the genera and subgenera of the Recent azooxanthellate Scleractinia (Cnidaria, Anthozoa), with an attached glossary. Zookeys 227: 1-47. http://dx.doi.org/10.3897/zookeys.227.3612

Császár G. (ed.) 1996: Magyarország litosztratigráfiai Alapegységei. Kréta. [Lithostratigraphic units of Hungary. Cretaceous.] - Hungarian Geological Institute, Budapest, 163 pp.

CsÁszÁR G. \& TURnŠEK D. 1996: Vestiges of atoll-like formations in the Lower Cretaceous of the Mecsek Mountains, Hungary. - Cretaceous Research 17: 419-442. http://dx.doi.org/10.1006/cres.1996.0026

Csontos L. 1995: Tertiary tectonic evolution of the Intra-Carpathian area: a review. - Acta Vulcanologica 7: 1-13.

Csontos L. \& Vörös A. 2004: Mesozoic plate tectonic reconstruction of the Carpathian region. - Palaeogeography, Palaeoclimatology, Palaeoecology 210: 1-56. http://dx.doi.org/10.1016/j.palaeo.2004.02.033

FőZY I. \& FOGARASI A. 2002: A gerecsei Bersek-hegy rétegtani tagolása az alsó-kréta ammoniteszfauna és a nannoplankton flóra alapján. (The Lower Cretaceous biostratigraphy of the Bersek Hill (Gerecse Mts, Transdanubian Range) on the basis of the ammonites and nannofossils.) - Földtani Közlöny 132(3-4): 293-324.

FöZY I. \& JANSSEN N. M. M. 2009: Integrated Lower Cretaceous biostratigraphy of the Bersek Quarry, Gerecse Mountains, Transdanubian Range, Hungary. - Cretaceous Research 30: 78-92. http://dx.doi.org/10.1016/j.cretres.2008.05.002

FülöP J. 1958: Die kretazeischen Bildungen des Gerecse-Gebirges. - Geologica Hungarica series Geologica 11: 57-88.

HantKen M. 1868: Lábatlan vidékének földtani viszonyai. [Geology around Lábatlan.] - $A$ Magyarhoni Földtani Társulat Munkálatai 4: 48-56.

HofmanN K. 1884: Jelentés 1883 nyarán Ószőny és Piszke között foganatosított földtani részletes felvételekről. (Bericht über die auf der rechten Seite der Donau zwischen Ó-Szőny und Piszke im Sommer 1883 ausgeführten geologischen Spezialaufnahmen.) - Földtani Közlöny 14: $174-190$. 
KÁZMÉR M. 1986: Tectonic units of Hungary: Their boundaries and stratigraphy (A bibliographic guide). - Annales Universitatis Scientiarum Budapestiensis de Rolando Eötvös Nominatae, sectio Geologica 26: 45-120.

KolosváRY G. 1954: Magyarország kréta-időszaki koralljai. (Les coralliaires du Crètacé de la Hongrie.) - Annales Instituti Geologici Publici Hungarici 42(2): 67-128.

KolosvÁRY G. 1957: Új korallok a Lábatlani alsókréta időszaki rétegekből. (Neue Korallen aus den unterkretazeischen Schichten von Lábatlan.) - Földtani Közlöny 87: 81-84.

Kolosváry G. 1959: Korallen aus der Unterkreide des Mecsek-Gebirges. - Acta Biologica 5: 125-128.

LÖSER H. 2013: Revision of the family Asteroseriidae (Cretaceous). - Geodiversitas 35: 23-31. http://dx.doi.org/10.5252/g2013n1a2

Löser H., Castro J. M. \& Nieto L. M. 2013: Late Albian Scleractinian corals from the Prebetic Zone (SE Spain). - Palaeontographica 301: 1-62. 